\title{
Human milk banks in the response to COVID-19: a statement of the regional human milk bank network for Southeast Asia and beyond
}

Estrella Olonan-Jusi ${ }^{1}$, Paul G. Zambrano ${ }^{2^{*}}$ (D, Vu H. Duong ${ }^{3}$, Nguyen T. T. Anh ${ }^{4}$, Nant S. S. Aye ${ }^{5}$, Mei Chien Chua ${ }^{6}$, Hikmah Kurniasari ${ }^{7}$, Zaw Win Moe ${ }^{8}$, Sopapan Ngerncham ${ }^{9}$, Nguyen T. T. Phuong ${ }^{10}$ and Janice Datu-Sanguyo ${ }^{11}$

\begin{abstract}
Background: The World Health Organization (WHO) recommendations on infant feeding in the context of COVID19 uphold standing recommendations for breastfeeding, non-separation, and skin-to-skin contact, including the use of donor human milk when mother's own milk is not available.

Insufficient guidance on the use of donor human milk and the role of human milk banks in the pandemic response: COVID-19 clinical management guidelines in seven countries in Southeast Asia are not aligned with WHO recommendations despite the lack of evidence of transmission through either breastmilk or breastfeeding. The use of safe donor human milk accessed through human milk banks is also insufficiently recommended, even in countries with an existing human milk bank, leading to a gap in evidence-based management of COVID-19. This highlights long-standing challenges as well as opportunities in the safe, equitable, and resilient implementation of human milk banks in the region.

Conclusions: This statement reflects the expert opinion of the Regional Human Milk Bank Network for Southeast Asia and Beyond on the need to revisit national guidelines based on the best evidence for breastfeeding during the COVID-19 pandemic, to incorporate human milk bank services in national obstetric and newborn care guidelines for COVID-19 where possible, and to ensure that operations of human milk banks are adapted to meet the needs of the current pandemic and to sustain donor human milk supply in the long-term. The Network also recommends sustained engagement with the global human milk bank community.
\end{abstract}

Keywords: COVID-19, Human milk bank, Breastfeeding, Donor human milk, Pasteurization, Regional network

\section{Background}

The COVID-19 pandemic has affected all ten member states of the Association of Southeast Asian Nations or ASEAN. All countries have taken measures to limit transmission of the virus, and for those with severe illness to receive appropriate, life-saving treatment. As the

\footnotetext{
* Correspondence: pzambrano@fhi360.org

${ }^{2}$ Alive \& Thrive Southeast Asia/FHI 360, 1101 Quezon City, Philippines Full list of author information is available at the end of the article
}

world learns more about the virus, and how best to respond to the threat, the need for evidence-based approaches in all aspects of the COVID-19 response remains paramount.

Even before the pandemic, global evidence on the role of breastfeeding in preventing maternal and child illness and death, and its long-term health and economic impact for children, mothers, and even nations is stronger than it has ever been $[1,2]$. The COVID-19 pandemic

(C) The Author(s). 2021 Open Access This article is licensed under a Creative Commons Attribution 4.0 International License, which permits use, sharing, adaptation, distribution and reproduction in any medium or format, as long as you give appropriate credit to the original author(s) and the source, provide a link to the Creative Commons licence, and indicate if changes were made. The images or other third party material in this article are included in the article's Creative Commons licence, unless indicated otherwise in a credit line to the material. If material is not included in the article's Creative Commons licence and your intended use is not permitted by statutory regulation or exceeds the permitted use, you will need to obtain permission directly from the copyright holder. To view a copy of this licence, visit http://creativecommons.org/licenses/by/4.0/ The Creative Commons Public Domain Dedication waiver (http://creativecommons.org/publicdomain/zero/1.0/) applies to the data made available in this article, unless otherwise stated in a credit line to the data. 
has not diminished this evidence. While a number of case studies reported the detection of SARS-CoV-2 RNA in breastmilk samples of women who tested positive for COVID-19 [3-5], more robust research suggests that breastmilk is not a route of vertical transmission [6]. Antibodies for SARS-CoV-2 have even been detected in breastmilk, suggesting a potential protective benefit $[7,8]$.

The World Health Organization (WHO) recommends that mothers with suspected or confirmed COVID-19 should not be separated from their infants, and breastfeeding recommendations practiced with additional infection prevention and control measures such as mask wearing, hand hygiene and wiping of surfaces [9]. Health facilities and staff are also advised to support mothers to initiate breastfeeding within one hour of birth, practice skin-to-skin contact, to share a room, and to continue to breastfeed safely [10]. WHO advises that newborn care guidelines must be based on a full consideration of not only the potential risk of COVID-19 infection of the infant, but also the risks of morbidity and mortality associated with not breastfeeding, the deprivation of the protective effects of skin-to-skin contact, and the risks associated with breastmilk substitutes [11].

\section{Insufficient guidance on the use of donor human milk and the role of human milk banks in the pandemic response}

\section{Inconsistencies in country guidelines}

Despite the clear recommendations and supporting evidence, governmental and professional medical association guidelines on obstetric and newborn care for COVID-19 in countries in Southeast Asia were inconsistent with WHO guidance. A review of guidelines on pregnancy, intrapartum and postpartum care in the context of COVID-19 from 33 countries, including seven in Southeast Asia, collected from 21 March and 30 April 2020, found that Indonesia, Malaysia, the Philippines, and Singapore did not recommend skin-to-skin contact, early initiation of breastfeeding and rooming-in for mothers with confirmed COVID-19 [12]. Thailand also did not recommend skin-to-skin contact and early initiation but allowed rooming-in with two meters distance between the mother and the infant based on family's preference [12]. There was no mention of skin-to-skin contact and early initiation of breastfeeding in the Myanmar and Vietnam guidelines, but Myanmar recommended unrestricted rooming-in while Vietnam recommended immediate separation [12]. Specific to infant feeding, Indonesia recommended direct breastfeeding with infection protection and control measures, Myanmar and the Philippines allowed breastfeeding based on family preference, while Malaysia, Singapore, Thailand, and Vietnam did not recommend it [12]. If direct breastfeeding is not possible, Myanmar,
Philippines and Vietnam recommended the provision of expressed breastmilk [12]. It is also noteworthy that only the Vietnam guidelines explicitly recommended the provision of donor human milk when indicated [12].

Some of the countries later updated their guidelines or issued related guidelines to align with the WHO recommendations. The Thailand guidelines for care of newborns who were born from mothers with suspected or confirmed COVID-19 issued in April 2020 and the Philippines guidelines for the management of women about to give birth and newborns issued in July 2020 allowed skin-to-skin contact, early initiation of breastfeeding and direct breastfeeding under strict droplets precaution based on the mother's preference after proper counselling $[13,14]$. The KK Women's and Children's Hospital in Singapore, one of the largest hospitals in the country, issued its own guidance for breastfeeding and breastmilk feeding of infants of mothers who are suspected or confirmed to have COVID-19 in May 2020, which allowed rooming-in, direct breastfeeding with infection protection and control measures and feeding of expressed breastmilk based on mother's decision after proper counselling [see Additional file 1]. The revised guidelines from Indonesia issued in September 2020 allowed early initiation of breastfeeding, direct breastfeeding with infection control measures and the provision of expressed breastmilk upon family's preference according to clinical conditions and after receiving education [15]. The Philippines, Thailand and the KK Women's and Children's Hospital in Singapore also recommended the provision of donor human milk as a feeding option for infants of mothers with confirmed COVID-19 [13, 14].

\section{The role of donor human milk banks in a holistic COVID- 19 response}

For vulnerable infants (e.g. preterm, low birthweight, severely ill) who are unable to breastfeed or access their own mother's milk, WHO recommends the safe use of donor human milk [16], and reiterated this in the guidance for COVID-19 [9]. When included in a package of interventions to protect, promote, and support breastfeeding, having access to donor human milk can protect the already vulnerable infant from life-threatening complications [17] and help mothers to establish their own milk supply and improve breastfeeding outcomes [18-20]. Human milk banks play a significant role in their function to screen and recruit breastmilk donors, and then to collect, process, screen, store and distribute safe donor human milk [21]. Studies show that the process of Holder pasteurization of donor human milk, which is routinely done in human milk banks, can inactivate the SARS-CoV2 virus [22, 23]. 
Table 1 Human milk banks in Southeast Asia (as of December 2020)

\begin{tabular}{|c|c|c|c|}
\hline Country & Facility & $\begin{array}{l}\text { City or } \\
\text { Province }\end{array}$ & Recipients of donor human milk \\
\hline \multirow[t]{3}{*}{ Myanmar } & Yangon Central Women's Hospital & Yangon & Preterm, low birthweight and sick infants in hospital \\
\hline & Yangon Children's Hospital & & \\
\hline & Yankin Children's Hospital & & \\
\hline \multirow[t]{25}{*}{ Philippines } & $\begin{array}{l}\text { Baguio General Hospital and Medical } \\
\text { Center }\end{array}$ & Baguio City & $\begin{array}{l}\text { Preterm, low birthweight and sick infants in hospital; infants in need of } \\
\text { donor human milk in humanitarian settings }\end{array}$ \\
\hline & Batangas Medical Center & Batangas City & \\
\hline & Southern Philippines Medical Center & Davao City & \\
\hline & Western Visayas Regional Medical Center & Iloilo City & \\
\hline & Ospital ng Malabon & Malabon City & \\
\hline & Bangkal Health Center & Makati City & \\
\hline & Makati Medical Center & & \\
\hline & Dr. Jose Fabella Memorial Hospital & Manila & \\
\hline & Justice Jose Abad Santos General Hospital & & \\
\hline & Ospital ng Maynila Medical Center & & \\
\hline & Philippine General Hospital & & \\
\hline & Bicol Medical Center & Naga City & \\
\hline & Pasig City General Hospital & Pasig City & \\
\hline & Rizal Medical Center & & \\
\hline & The Medical City & & \\
\hline & East Avenue Medical Center & Quezon City & \\
\hline & Philippine Children's Medical Center & & \\
\hline & Quezon City General Hospital & & \\
\hline & Quirino Memorial Medical Center & & \\
\hline & Jose B. Lingad Memorial Regional Hospital & $\begin{array}{l}\text { San Fernando } \\
\text { City }\end{array}$ & \\
\hline & Eastern Visayas Regional Medical Center & Tacloban City & \\
\hline & St. Luke's Medical Center - Global City & Taguig City & \\
\hline & Taguig District Hospital & & \\
\hline & Cagayan Valley Medical Center & Tuguegarao & \\
\hline & Zamboanga City Medical Center & $\begin{array}{l}\text { Zamboanga } \\
\text { City }\end{array}$ & \\
\hline Singapore & KK Women's and Children's Hospital & Singapore & $\begin{array}{l}\text { Preterm, low birthweight and sick infants in hospital; infants in need of } \\
\text { donor human milk in the community }\end{array}$ \\
\hline \multirow[t]{4}{*}{ Thailand } & $\begin{array}{l}\text { Faculty of Medicine Siriraj Hospital, } \\
\text { Mahidol University }\end{array}$ & Bangkok & Preterm, low birthweight and sick infants in hospital \\
\hline & $\begin{array}{l}\text { Faculty of Medicine Ramathibodi Hospital, } \\
\text { Mahidol University }\end{array}$ & Bangkok & \\
\hline & Faculty of Medicine, Chiang Mai University & $\begin{array}{l}\text { Chiang Mai } \\
\text { Province }\end{array}$ & \\
\hline & $\begin{array}{l}\text { Faculty of Medicine, Prince of Songkla } \\
\text { University }\end{array}$ & $\begin{array}{l}\text { Songkla } \\
\text { Province }\end{array}$ & \\
\hline \multirow[t]{3}{*}{ Vietnam } & $\begin{array}{l}\text { Da Nang Hospital for Women and } \\
\text { Children }\end{array}$ & Da Nang & $\begin{array}{l}\text { Preterm, low birthweight and sick infants in hospital; infants in need of } \\
\text { donor human milk in the community }\end{array}$ \\
\hline & Tu Du Maternity Hospital & $\begin{array}{l}\text { Ho Chi Minh } \\
\text { City }\end{array}$ & \\
\hline & Quang Nam General Hospital & $\begin{array}{l}\text { Quang Nam } \\
\text { Province }\end{array}$ & \\
\hline
\end{tabular}


A total of 35 human milk banks are currently operating in five countries in Southeast Asia (Table 1), with a formal milk bank association convened in only one country (the Philippines). While there is currently insufficient data to accurately assess scale [24], human milk bank services play a critical role in providing donor human milk for vulnerable infants, especially during this crisis. As such, in countries with an established human milk bank, COVID-19 country guidelines should explicitly recommend the use of pasteurized donor human milk as a feeding option when a mother's own milk is not available. The role of human milk banks in clinical management of COVID-19 needs to be integrated and clearly defined in newborn care guidelines. This is a prerequisite for full alignment with the evidence-based recommendations of WHO.

\section{Challenges and opportunities}

Outside of the recommendation on the use of donor human milk in the hierarchy of feeding options, there are currently no WHO guidelines specific to the operation of human milk banks. Countries have thus far relied on existing recommendations from regional milk bank associations [25, 26], expert groups [27], and other countries to inform local standards development. There is also relatively limited guidance regarding donor screening, raw milk handling, collection, and transport of donor human milk in the context of the pandemic, as well as guidance on long-term operational considerations for human milk banks in a post-pandemic setting. While some countries have included disaster risk reduction and response considerations in the operation of their human milk banks prior to the pandemic (e.g. dedicated emergency response supply in the Philippines), human milk banks in the region are generally not designed, nor are currently sufficient in capacity, to respond to large-scale emergencies, especially one as complex as COVID-19. The current pandemic is an opportunity to accelerate the development of WHO guidelines, to advocate for interventions to increase coverage of human milk bank services, or to establish human milk banks in countries where no such services are in place. It is also an opportunity to establish and sustain global partnerships to advance human milk banking through knowledge sharing and joint advocacy. This opportunity has not gone unrecognized. The global human milk bank community recently convened and issued a call to action [24], articulating the need to address fundamental bottlenecks to ensuring safe, equitable, and resilient implementation of human milk bank services in the context of COVID19 and beyond.

\section{Conclusions}

The aim of this paper is to highlight the need for alignment with WHO guidance on infant feeding in the context of COVID-19, including the need to ensure that human milk bank services are included in the evidencebased package of services for vulnerable infants during the pandemic and beyond.

Given the evolving situation in the region, we, the Regional Human Milk Bank Network for Southeast Asia and Beyond, are a growing network of neonatologists, human milk banking experts, breastfeeding advocates, and infant and young child nutrition experts. We recommend the following to ministries of health, professional associations, and fellow human milk bank practitioners in the region:

1. Revisit and update guidelines that recommend the separation of mothers and infants if the mother has suspected or confirmed COVID-19. The short- and long-term risk of this separation, including disruption of breastfeeding, must be weighed against the potential risk of transmission of COVID-19 using the best available evidence.

2. In the development or updating of national guidelines for obstetric and newborn care in the context of COVID-19:

a. Ensure that the WHO recommended hierarchy of feeding options is followed, with breastfeeding and feeding with mother's expressed milk prioritized. This can be followed by safe donor human milk from a human milk bank should separation be required or unavoidable (e.g. if the mother is severely ill). Wet nursing may be explored if culturallyacceptable, feasible, and supported by national guidelines [9].

b. Link human milk bank services to clinical management guidelines, and require additional, appropriate safety measures and precautions during raw milk collection, processing, and use (see Additional file 2).

c. Ensure that breastfeeding is protected, promoted, and supported, especially for mothers with suspected or confirmed COVID-19.

3. Adapt human milk bank operations to meet the needs of the current pandemic and to sustain donor human milk supply in the long-term.

4. Contribute to the global learning and research agenda by documenting experiences and lessons learned with human milk banks in the COVID-19 response.

5. Maintain active engagement with regional and global communities of practice such as the Virtual Communication Network of milk bank leaders established in March 2020 [24]. 


\section{Supplementary Information}

The online version contains supplementary material available at https://doi. org/10.1186/s13006-021-00376-2.

Additional file 1. KKHospital Guidance. Guidance on Breastfeeding and Breast Milk Feeding for Suspect and Confirmed COVID-19 - KK Women's and Children's Hospital, Singapore. Guidance on Breastfeeding and Breast Milk Feeding for Suspect and Confirmed COVID-19 - KK Women's and Children's Hospital, Singapore.

Additional file 2. Additional recommendations. Additional recommendations for safe collection and processing of donor human milk during the COVID-19 pandemic. Presents additional measures to enhance safety procedures for donor screening and breastmilk expression to prevent possible contamination of collected donor human milk.

\section{Acknowledgements}

The authors are grateful to the contributions of staff and consultants of Alive \& Thrive Southeast Asia, specifically Jennifer Cashin, Chan Myae Aung, Sedtha Chin, Putu Widhiantara, and Binh Ta for their support in collecting available country guidelines and initial editorial work. The authors are also grateful to Roger Mathisen and Joy Del Rosso from Alive \& Thrive Southeast Asia and Headquarters, respectively, for their comments and suggestions for improving this statement. Lastly, the authors are grateful to global Human Milk Bank expert Gillian Weaver from the UK, for her feedback which helped improve the statement and its consistency with other global calls to action.

\section{Authors' contributions}

The authors initiated the manuscript via group discussion. All authors contributed to the drafting of the manuscript and revised the manuscript. All authors agreed to the final manuscript and consent to publication in International Breastfeeding Journal. The authors read and approved the final manuscript.

\section{Authors' information}

Estrella Olonan-Jusi, President, Human Milk Bank Association of the Philippines, Manila, Philippines.

Paul G Zambrano, Regional Technical Advisor, Alive \& Thrive Southeast Asia/ FHI360, Quezon City, Philippines.

Vu H Duong, Technical Specialist, Alive \& Thrive Southeast Asia/FHI360, Hanoi, Vietnam.

Nguyen TT Anh, Neonatologist and Head of Human Milk Bank, Tu Du Hospital, Ho Chi Minh City, Vietnam.

Nant SS Aye, Clinical Professor (Neonatology), Neonatal Intensive Care Unit, Central Women's Hospital, Yangon, Myanmar.

Mei Chien Chua, Senior Consultant and Head of the Department of Neonatology and KK Human Milk Bank, KK Women's and Children's Hospital, Singapore.

Hikmah Kurniasari, General Practitioner and IBCLC, Human Milk Bank Initiative Association of Indonesia, Jakarta, Indonesia.

Zaw Win Moe, Senior Consultant/Neonatologist, Neonatal Intensive Care Unit, Yankin Children's Hospital, Yangon, Myanmar.

Sopapan Ngerncham, Associate Professor of Pediatrics, Siriraj Human Milk

Bank, Department of Pediatrics, Faculty of Medicine Siriraj Hospital, Mahidol University, Bangkok, Thailand.

Nguyen TT Phuong, Neonatologist, Human Milk Bank, Da Nang Hospital for Women and Children, Da Nang, Vietnam

Janice Datu-Sanguyo, Consultant, Alive \& Thrive Southeast Asia/FHI360, Manila, Philippines

\section{Funding}

This statement was supported in part by the Bill \& Melinda Gates Foundation (Grant Number OPP50838). The funding body had no role in the collection, analysis, or interpretation of data, or in the writing of the statement. The views and opinions set out in this article represent those of the authors, and do not necessarily represent the position of the funding body.

\section{Availability of data and materials}

Not applicable.

\section{Declarations}

Ethics approval and consent to participate

Not applicable.

\section{Consent for publication}

Not applicable.

\section{Competing interests}

The authors declare that they have no competing interests.

\section{Author details}

${ }^{1}$ Human Milk Bank Association of the Philippines, Manila, Philippines. ${ }^{2}$ Alive \& Thrive Southeast Asia/FHI 360, 1101 Quezon City, Philippines. ${ }^{3}$ Alive \& Thrive Southeast Asia/FHI 360, Hanoi, Vietnam. ${ }^{4}$ Human Milk Bank, Tu Du Hospital, Ho Chi Minh City, Vietnam. ${ }^{5}$ Neonatal Intensive Care Unit, Central Women's Hospital, Yangon, Myanmar. ${ }^{6}$ Department of Neonatology and KK Human Milk Bank, KK Women's and Children's Hospital, Singapore, Singapore.

${ }^{7}$ Human Milk Bank Initiative Association of Indonesia, Jakarta, Indonesia. ${ }^{8}$ Neonatal Intensive Care Unit, Yankin Children's Hospital, Yangon, Myanmar. ${ }^{9}$ Siriraj Human Milk Bank, Department of Pediatrics, Faculty of Medicine Siriraj Hospital, Mahidol University, Bangkok, Thailand. ${ }^{10}$ Human Milk Bank, Da Nang Hospital for Women and Children, Da Nang, Vietnam. ${ }^{11}$ Alive \& Thrive Southeast Asia/FHI 360, Manila, Philippines.

Received: 11 September 2020 Accepted: 16 March 2021

Published online: 29 March 2021

\section{References}

1. Rollins NC, Bhandari N, Hajeebhoy N, Horton S, Lutter CK, Martines JC, Piwoz EG, Richter LM, Victora CG. Why invest, and what it will take to improve breastfeeding practices? Lancet. 2016;387(10017):491-504. https://doi.org/1 0.1016/S0140-6736(15)01044-2

2. Walters DD, Phan LTH, Mathisen R. The cost of not breastfeeding: global results from a new tool. Health Policy Plan. 2019;34(6):407-17. https://doi. org/10.1093/heapol/czz050

3. Groß R, Conzelmann C, Muller JA, Stenger S, Steinhart K, Kirchhoff F, et al, Detection of SARS-CoV-2 in human breastmilk. Lancet. 2020;395(10239): 1757-8. https://doi.org/10.1016/S0140-6736(20)31181-8.

4. Costa S, Posteraro B, Marchetti S, Tamburrini E, Carducci B, Lanzone A, Valentini $P$, Buonsenso D, Sanguinetti M, Vento G, Cattani P. Excretion of SARS-CoV-2 in human breast milk. Clin Microbiol Infect. 2020:26(10):1430-2. https://doi.org/10.1016/j.cmi.2020.05.027.

5. Tam PCK, Ly KM, Kernich ML, Spurrier N, Lawrence D, Gordon D, et al. Detectable Severe Acute Respiratory Syndrome Coronavirus 2 (SARS-CoV-2) in human breast milk of a mildly symptomatic patient with coronavirus disease 2019 (COVID-19). Clin Infect Dis. 2020:ciaa673.

6. Chambers C, Krogstad P, Bertrand K, Contreras D, Tobin N, Bode L. Evaluation for SARS-CoV-2 in breast milk from 18 infected women. JAMA. 2020;324(13):1347-8. https://doi.org/10.1001/jama.2020.15580.

7. Dong Y, Chi X, Hai H, Sun L, Zhang M, Xie W, et al. Antibodies in the breast milk of a maternal woman with COVID-19. Emerg Microbes Infect. 2020;9(1): 1467-9. https://doi.org/10.1080/22221751.2020.1780952.

8. Fox A, Marino J, Amanat F, Krammer F, Hahn-Holbrook J, Zolla-Pazner Evidence of a significant secretory-lgA-dominant SARS-CoV-2 immune response in human milk following recovery from COVID-19; 2020. https:// doi.org/10.1101/2020.05.04.20089995v1.

9. World Health Organization (WHO). Clinical management of Covid-19 Interim guidance (dated 27 May 2020). Available at https:/www.who.int/ publications/i/item/clinical-management-of-severe-acute-respiratoryinfection-when-novel-coronavirus-(ncov)-infection-is-suspected. Accessed 8 Jan 2021.

10. World Health Organization (WHO). Frequently Asked Questions: Breastfeeding and COVID-19 for health care workers (dated 12 May 2020). Available at https:/www.who.int/docs/default-source/maternal-health/faqsbreastfeeding-and-covid-19.pdf?sfvrsn=d839e6c0_1. Accessed 8 Jan 2021.

11. World Health Organization (WHO). Breastfeeding and COVID-19 - Scientific Brief (dated 23 July 2020). Available at https://www.who.int/news-room/ commentaries/detail/breastfeeding-and-covid-19. Accessed 8 Jan 2021. 
12. Vu Hoang D, Cashin J, Gribble K, Marinelli K, Mathisen R. Misalignment of global COVID-19 breastfeeding and newborn care guidelines with World Health Organization recommendations. BMJ Nutr Prev Health. 2020;3:339-50.

13. Yangthara B, Chokephaibulkit K, Wongsiridej P; The Royal College Pediatricians of Thailand, Pediatric Society of Thailand. Care of newborns who were born from mothers with suspected or confirmed COVID-19 (updated 08/05/2020). Available at http://www.thaipediatrics.org/pages/ People/Detail/46/289. Accessed 8 Jan 2021.

14. Department of Health, Republic of the Philippines. Department Memorandum 2020-0319 on the Interim Guidelines on COVID-19 Management of Pregnant Women, Women About to Give Birth, and Newborns (dated 13 July 2020). Available at https://doh.gov.ph/node/23951. Accessed 8 Jan 2021.

15. Ministry of Health, Republic of Indonesia. Antenatal Service, Labor and Care for Newborn Guidelines (dated September 2020). Available at https://covid1 9.go.id/storage/app/media/Materi\%20Edukasi/2020/Oktober/revisi-2-a5pedoman-pelayanan-antenatal-persalinan-nifas-dan-bbl-di-era-adaptasi-kebia saan-baru.pdf. Accessed 24 Feb 2021.

16. World Health Organization (WHO). Donor human milk for low-birth-weight infants, updated 22 July 2019. Available at https://www.who.int/elena/titles/ donormilk_infants/en/. Accessed 8 January 2021.

17. Quigley M, Embleton ND, McGuire W. Formula versus donor breast milk for feeding preterm or low birth weight infants. Cochrane Database Syst Rev. 2019;7(7):CD002971.

18. Kair LR, Flaherman VJ. Donor milk or formula: a qualitative study of postpartum mothers of healthy newborns. J Hum Lact. 2017;33(4):710-6. https://doi.org/10.1177/0890334417716417.

19. Merjaneh N, Williams $P$, Inman S, Shumacher M, Smotherman C, Alissa R, et al. The impact on the exclusive breastfeeding rate at 6 months of life of introducing supplementary donor milk into the level 1 newborn nursery. $J$ Perinatol. 2020;40(7):1109-14. https://doi.org/10.1038/s41372-020-0657-6.

20. Kantorowska A, Wei JC, Cohen RS, Lawrence RA, Gould JB, Lee HC. Impact of donor milk availability on breast milk use and necrotizing enterocolitis rates. Pediatrics. 2016;137(3):e20153123. https://doi.org/10.1542/peds.201 5-3123.

21. Israel-Ballard K, Cohen J, Mansen K, Parker M, Engmann C, Kelley M. OxfordPATH human Milk working group. Call to action for equitable access to human milk for vulnerable infants. Lancet Glob Health. 2019;7(11):e1484-6. https://doi.org/10.1016/S2214-109X(19)30402-4.

22. Unger S, Christie-Holmes N, Guvenc F, Budylowski P, Mubareka S, GrayOwen SD, et.al. Holder pasteurization of donated human milk is effective in inactivating SARS-CoV-2. CMAJ. 2020;192:E871-E874, 31, DOl: https://doi. org/10.1503/cmaj.201309.

23. Walker GJ, Clifford V, Bansal N, Stella AO, Turville S, Stelzer-Braid S, Klein LD, et al. SARS-CoV-2 in human milk is inactivated by Holder pasteurisation but not cold storage. J Paediatr Child Health. 2020. https://doi.org/10.1111/jpc.1 5065 .

24. Shenker N. Virtual collaborative network of human Milk banks associations. Maintaining safety and service provision in human milk banking: a call to action in response to the COVID-19 pandemic. Lancet Child Adolesc Health. 2020;4(7):484-5. https://doi.org/10.1016/52352-4642(20)30134-6.

25. Weaver G, Bertino E, Gebauer C, Grovslien A, Mileusnic-Milenovic R, Arslanoglu S, et.al. Recommendations for the establishment and operation of human milk banks in Europe: a consensus statement from the European Milk Bank Association (EMBA). Front Pediatr 2019;7:53, DOl: https://doi.org/1 0.3389/fped.2019.00053.

26. Human Milk Banking Association of North America (HMBANA). HMBANA Standards for Donor Human Milk Banking: An Overview, Public Version 1.0 (2020). Available at https://www.hmbana.org/file_download/inline/95a03 62a-c9f4-4f15-b9ab-cf8cf7b7b866. Accessed 26 Feb 2020.

27. PATH. Strengthening human milk banking: A resource toolkit for establishing and integrating human milk bank programs - A global implementation framework, Version 2.0 (2019). Available at https://www.pa th.org/programs/maternal-newborn-child-health-and-nutrition/ strengthening-human-milk-banking-resource-toolkit/. Accessed 26 Feb 2021.

\section{Publisher's Note}

Springer Nature remains neutral with regard to jurisdictional claims in published maps and institutional affiliations.

Ready to submit your research? Choose BMC and benefit from:

- fast, convenient online submission

- thorough peer review by experienced researchers in your field

- rapid publication on acceptance

- support for research data, including large and complex data types

- gold Open Access which fosters wider collaboration and increased citations

- maximum visibility for your research: over $100 \mathrm{M}$ website views per year

At BMC, research is always in progress.

Learn more biomedcentral.com/submissions 